\title{
Expedience of Investing in the Intellectual Potential of an Enterprise Using the Example of PJSC Gazprom
}

\author{
Nina Baranova*, Daria Loginova \\ Peoples' Friendship University of Russia (RUDN), 6, Miklukho-Maklaya Str., Moscow 117198, Russia \\ *Corresponding author. Email: baranova_nm@pfur.ru
}

\begin{abstract}
One of the most important enterprise resources, ensuring its competitive advantage in the Russian and international markets, is its personnel with their knowledge, skills, smart ideas, effectively developing innovative projects and implementing them. Professionals are able to significantly increase the value and income of the company, raise its position. Therefore, the need to invest in the intellectual potential of the company is relevant. To study this issue, a regression analysis and an econometric modeling of the company's competitiveness were carried out through the dependence of its profit on some parameters characterizing the intellectual potential of the enterprise, using the example of Gazprom Corporation. The Eviews 10 application package was used. To that end, the works of Russian and foreign scientists were studied, the statistical data of the Annual reports on the activities of PJSC Gazprom for 2000-2018 were used. As a result of the study, it was found that the intellectual potential of the enterprise increases the value of the organization and its competitiveness. The resulting econometric model provides an opportunity to forecast in the short term. The WEF data in Davos for 2017-2019 indicate that Russia ranks $43^{\text {rd }}$ in the global competitiveness rating and $25^{\text {th }}$ in terms of innovation activity. Russia has a chance to get into the Top 10 in terms of innovation development, however, this will require significant cash injections and high-quality human capital.
\end{abstract}

Keywords: intellectual potential, $R \& D$, competitiveness, investments, econometric modeling, PJSC Gazprom

\section{INTRODUCTION}

PJSC Gazprom is one of the leading world-class Russian companies in the production, transportation, storage, processing, sale of oil and gas, production and sale of thermal energy and electricity. PJSC Gazprom shares are liquid securities in the Russian stock market and are a reliable way to invest. Dividends on them are constantly growing. Average dividend yield on shares for 2012-2013 amounted to about $3 \%$ per year, in $2015-5.5 \%$. It is assumed that in 2020 the return on equity and dividends will remain unchanged or rise to $6 \%$. [1-2]

There are explicit and implicit factors that can affect the stock value. The explicit factors include the following: long-term gas supply contracts to Europe, Turkey, China and other countries; state tax policy; increasing consumption of major gas consumers; national currency rate, etc. [3] Implicit factors include: development of the company's intellectual potential and its effective use [4]. The contribution of positive intellectual potential to the development of the enterprise is invaluable: it increases all the resources efficiency, competitiveness and value of the company, plays a significant role in its sustainable development and leadership [5-8].

\section{PROBLEM STATEMENT}

Currently, a large group of Russian and foreign scientists are engaged in researching the human resources development of the enterprise. These include studies by Israilova Z.R., Barzaeva M.A. [7], Timerbulatov R.M. [8], Antonenko V.V., Laktyuhina E.G., Antonov G.V. [9], Belkin V.N., Belkina N.A., Antonova O.A. [10] Rogalev N.D. [11] Khudyakova E.G. [12] and others. Issues of management and efficient use of human resources of the enterprise were considered by Lebon I., Rebière T. [4], Vandenberghe V. [5], Armstrong M., Taylor S. [13], Zambrano A. [14] and etc.

The challenge of sustainable development of the enterprise through the innovative component were addressed by Baranova N.M., Loginova D.S. [3], Graafland J., Noorderhaven N. [6], Bambi M., Di Girolami C., Federico S. [15], Fleurbaey M. [16], Pham T.A. [17], Ackerberg D.A., Caves K., Frazer G. [18] and others.

A study of the country's economic growth through its intellectual potential was carried out by Kim H., Hoskisson R.E., Lee S.H. [19], Asheim G. B., Mitra T. [20], Pilipenko A., Pilipenko Z. [21], Sergi B.S. [22-23], Matyushok V.M., Sorokin L.V. [24] et al.

Insignificant attention was paid to modeling the competitiveness of the enterprise through its intellectual potential assessment by industry, therefore let us undertake this study.

\section{PURPOSE OF THE STUDY}

The professionalism of employees plays a significant role in the implementation of large-scale projects [9]. Staff 
motivation system, investments in science, personnel training and development create all the conditions for attracting and retaining highly qualified employees and effectively solving the company's multilateral tasks [10]. Investments aimed at increasing the intellectual potential of the organization are the basis for building its human capital (hereinafter the HC). Obviously, investments in the corporation's HC today provide multiple future earnings for the organization [7].

\section{MATERIALS AND METHODS}

Various methods to assess the organization's HC as an important component of intellectual potential are available: (1) estimation of income value generated by the organization's HC; (2) quantifying the knowledge acquired by personnel, (3) measurement of special skills; (4) investment value assessment in the HC and others [23, 25]

Let us make an evaluation of the competitiveness of PJSC Gazprom for 2000-2018 through the assessment of its sales revenue using regression and econometric analysis in the Eviews10 application software package [24-27].

\section{RESEARCH QUESTIONS}

\subsection{Human Resource Management PJSC Gazprom}

There are required - (1) regular corporate education; (2) employee career planning; (3) continuity and mutual assistance; (4) staff motivation; (5) the formation and development of managerial staff; (6) regular assessment of professional skills and qualifications of employees, etc. to effectively use the potential of the company's employees, in particular PJSC Gazprom [1].

The main components of the corporate education system are the following [2]: (1) planning and coordination of education, its quality control and effectiveness; (2) modern effective forms of training; (3) development of the enterprise network of educational units in PJSC Gazprom, expansion of relations with educational institutions; (4) an individualized instruction and developing young specialists, etc.

PJSC Gazprom applies a comprehensive staff competitive selection system to attract qualified personnel, creates all opportunities for career development, interaction with educational institutions, takes measures to identify talents and attract them to work in the corporation $[1-2,11]$.

\subsection{Investment component of the intellectual potential of PJSC Gazprom}

Most of the funds invested by PJSC Gazprom in the organization's HC are aimed at (1) training and education, advanced training and professionalism, development of creative abilities, retraining; (2) labor and health protection, safety measures, etc.; (3) corporate events and leisure activities; (4) employee social compensation package; (5) staff incentives for improved performance, etc. [1]

Pursuing a consistent policy of developing future intellectual capital, PJSC Gazprom continues to increase investments in training and staff development, drawing on the best domestic and international practices. Training and development at the company takes place at all its levels, including all categories of personnel and target groups of potential employees. The strategic objectives of the enterprise determine the content of training programs. One of the innovative solutions for the development of the company's HC was the platform "Professionals 4.0": the creation of breakthrough flexible teams for the implementation of promising business projects. [2]

PJSC Gazprom involves the best IT staff, who managed to create 12 digital transformation programs, more than 500 digital projects, enter into partnership projects with the SPE Annual International Congress, etc.

The need for new qualified IT-specialists incentives the company to invest in the modern educational programs development process, in the training advanced digital personnel for the oil and gas industry [11]. PJSC Gazprom has its own powerful scientific and technical complex, with 8 research organizations and three design institutes, creates advanced scientific schools in the field of geology, mining, the creation of multi-level gas transportation systems, etc. Gazprom attracts more than 100 external institutes and research centers to R\&D programs. PJSC Gazprom pursues a focused policy in the field of effective intellectual property management, patenting expediency, etc. PJSC Gazprom is faced with the task of large-scale implementation of comprehensive $\mathrm{R} \& \mathrm{D}$ programs to create new technologies and scientific projects, taking into account the fastest possible response to the development prospects of the global hydrocarbon market and competing companies [ 1-2].

\subsection{Linear model}

The econometric model will be constructed according to the data in annual reports of PJSC Gazprom for 2000-2018 in order to study and assess the competitiveness of Gazprom Corporation for the short-term. [28-31] For this end, a linear equation [25-27] should be composed. The sales revenue (in million rubles) used is the endogenous variable $\mathrm{Y}$, for independent variables used are: X1 - the R\&D activities (in million rubles), commissioned by the enterprise; X2 - the staff number (in thousand people); X3 - the use of patents efficiency received by the enterprise (in million rubles); $\mathrm{X} 4$ - the environmental projects costs (in million rubles). To carry out the necessary calculations, determine the model parameters and their estimates, the Eviews10 application program should be used.

The pairwise correlation matrix was constructed to establish the closeness between the variables X1,..., X4 
$\mathrm{Y}^{\wedge}(\mathrm{REVENUE})=256,99 \mathrm{X} 1+11564,24 \mathrm{X} 2+184,45 \mathrm{X} 3+$ $+24,62$ X4 - 3715363

determination coefficients were distributed as follows: $\mathrm{R}_{\mathrm{YX} 1}=0.87, \mathrm{R}_{\mathrm{YX} 2}=0.88, \mathrm{R}_{\mathrm{YX} 3}=0.84, \mathrm{R}_{\mathrm{YX} 4}=0.96$ and closely linked. The correlation between the regressors X1 ... X3 is insignificant $(\mathrm{R}=0.6)$, but the correlation between the variables $\mathrm{X} 4$ and $\mathrm{X} 1 \ldots \mathrm{X} 3$ is strong $\left(\mathrm{R}_{\mathrm{X} 1 \mathrm{X} 4}=0.79\right.$, $\mathrm{R}_{\mathrm{X} 2 \times 4}=0.85, \mathrm{R}_{\mathrm{X} 3 \mathrm{X} 4}=0.85$ ). This suggests that the environmental projects costs are interconnected with the R\&D activities, the staff number, and the efficiency of using patents. Obviously, multicollinearity can be observed in the model; therefore, more detailed studies need to be made of the parameters and estimates of the desired equation.

Dependent Variable: $Y$

Method: Least Square

Date: $03 / 13 / 20$ Time: $16: 30$

Sample: 119

Included observations: 19

\begin{tabular}{lrlll}
\hline \hline \multicolumn{1}{c}{ Variable } & Coefficient & Std. Error & t-Statistic & Prob. \\
\hline \hline X1 & 256.9885 & 50.73327 & 5.065483 & 0.0002 \\
X2 & 11564.24 & 3221.020 & 3.590241 & 0.0030 \\
X3 & 184.4509 & 62.19816 & 2.965537 & 0.0102 \\
X4 & 24.61830 & 13.25759 & 1.856921 & 0.0845 \\
C & -3715363. & 1120368. & -3.316198 & 0.0051 \\
\hline \hline & & & & \\
R-squared & 0.977817 & Mean dependent var & 3469158. \\
Adjusted R-squared & 0.971479 & S.D. dependent var & 2384576. \\
S.E. of regression & 402707.7 & Akaike info criterion & 28.87074 \\
Sum squared resid & $2.27 \mathrm{E}+12$ & Schwarz criterion & 29.11928 \\
Log likelihood & -269.2721 & Hannan-Quinn criter. & 28.91281 \\
F-statistic & 154.2811 & Durbin-Watson stat & 1.639383 \\
Prob(F-statistic) & 0.000000 & & & \\
\hline \hline
\end{tabular}

Figure 1 Coefficients and estimation of linear model parameters

Source: estimated by the authors (Eviews10) [28-31]

Estimating the obtained data of Figure 1, it may be noted that the equation of the desired linear model is significant (Fstat $=154.28$, Prob $=0.00)$, and the determination coefficient is R2 $=0.978$ ( $97.8 \%$ of the total variation of the regressand is reproduced by the variation of the regressor). Parameters such as Probability and t-Statistic coefficients for regressors indicate their significance.

The significance of the desired equation and coefficient estimates make it possible to construct a linear model and analyze the relationship of the studied variables. Regression coefficients can be interpreted as follows: ceteris paribus (1) an increase in the $R \& D$ activities performed by the enterprise by 1 million rubles leads to an average increase in the Y by 257 million rubles per year; (2) increase in the staff number by 1000 people leads to an average increase in the $\mathrm{Y}$ by 11564 rubles per year; (3) increase in the use of patents efficiency received by the enterprise by 1 million rubles results in an average increase in the Y by 185 million rubles per year; (4) an increase in the environmental projects costs by 1 million rubles causes an average change in the $\mathrm{Y}$ of 25 million rubles per year.

The C-intercept of the equation has no meaningful interpretation.

Thus, the equation takes the form:
The fitted values of the $\mathrm{Y}^{\wedge}$ approximate well the dependence of the actual value of the $\mathrm{Y}$ on exogenous variables. To study autocorrelation of residues on normality, it should be examined the Jarque-Bera test, based on the sample in question (Figure 2).

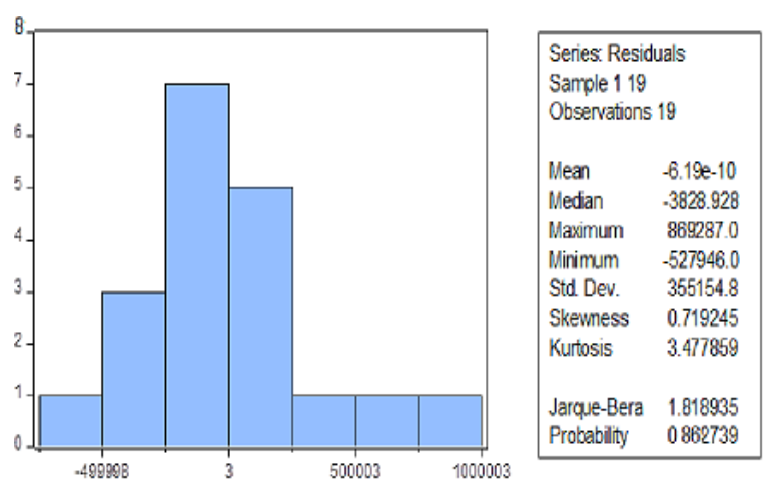

Figure 2 Jarque-Bera Test

Source: estimated by the authors (Eviews10) [28-31]

Considering the histogram of residuals (Figure 2), in particular, the Jarque-Bera test, it was found that the residuals of the equation of model (1) are normally distributed (1.82), and the Probability $=0.86$, that is the probability of accepting the null hypothesis $\mathrm{H} 0=86 \%$.

It can be established the adequacy of the desired model (1) by constructing a confidence interval and a graph of the fitted $\mathrm{Y}^{\wedge}$ (Figure 3).

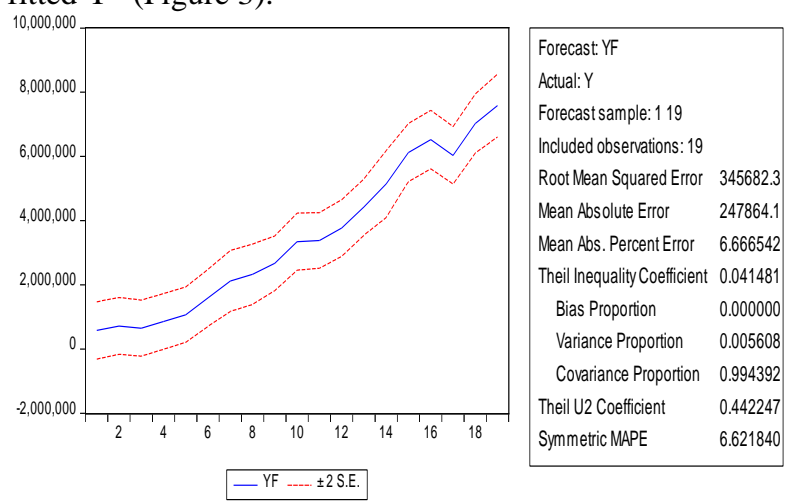

Figure 3 Graph and confidence interval $Y^{\wedge}(E D U C)$, model estimation parameters (1)

Source: estimated by the authors (Eviews10) [28-31]

The high accuracy of the obtained model is confirmed by the Theil inequality coefficient of $0.04(0<0.04<1)$, and the mean abs. percent error of the equation $(6.7 \%)$, (Figure 3).

The Goldfeld-Quandt test will check the equation (1) for the heteroskedasticity absence. The hypothesis H0: the dispersion of residues does not depend on regressors, and H1 is the opposite hypothesis. Since RSS3> RSS1, the 
hypothesis $\mathrm{H0}$ is accepted, and there is no need to calculate the RSS3 / RSS1 test statistics.

White test also enables to investigate model (1) for the heteroskedasticity. Hypothesis HO considers the proposal that there is no homoskedasticity of the residuals of equation (1), and $\mathrm{H} 1$ is the opposite hypothesis. Examining the results of the White test (Figure 4), it is arguable that the value of White test statistics is Obs * R2 $=12.25$, and the corresponding P-value is 0.59 , that is the Ho hypothesis of heteroskedasticity of residues (1) is rejected. Thus, the residues have a constant dispersion.

Heteroskedasticity Test: White

\begin{tabular}{llll}
\hline \hline & & & \\
F-statistic & 0.518765 & Prob. F(14,4) & 0.8384 \\
Obs*R-squared & 12.25207 & Prob. Chi-Square(14) & 0.5861 \\
Scaled explained SS & 8.241476 & Prob. Chi-Square(14) & 0.8764 \\
\hline \hline
\end{tabular}

Figure 4 White test

Source: estimated by the authors (Eviews10) [28-31]

It should be checked the model for adequacy and for the presence of autocorrelation using the Durbin-Watson statistic. From the evaluation of the equation (1) of Figure 2, it follows that the Darbin-Watson coefficient (DW) is 1.64. The upper bound of the statistics is DW $=1.58$ at the $1 \%$ significance level and does not reach 2 provided that the number of observations is $\mathrm{n}=19$ and four regressors. Consequently $\mathrm{r} \approx 0$, this indicates the absence of autocorrelation (du $<1,64<4$-du). Therefore, the hypothesis of positive autocorrelation is rejected.

As can be seen from the above, the model (1) is adequate and can be used to calculate the $\mathrm{Y}^{\wedge}$ for the short-term.

The exponential model turned out to be inadequate for the given parameters (Figure 5). Estimates of the Prob and tStat parameters for constructing an exponential equation indicate the inappropriateness of using this model for research and forecasting, that is why, it will not be considered.

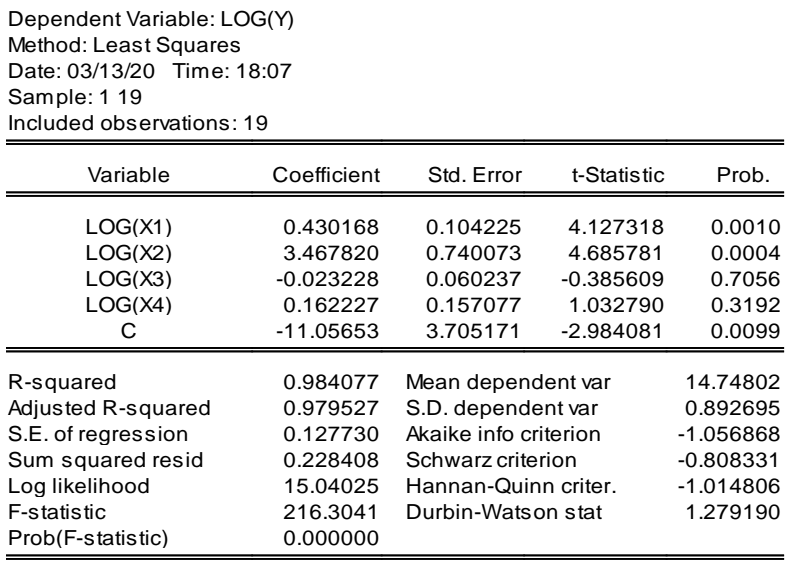

Figure 5 Parameters and estimates of the nonlinear equation

Source: estimated by the authors (Eviews10) [28-31]
Therefore, to study this problem, it is worth using the model (1) of linear regression.

\section{RESULTS}

According to expert opinion of PJSC Gazprom, investments in the intellectual potential of the company are the most promising, since modern technologies will be meaningless without competent and creative specialists with their knowledge, skills, experience.

Using the official reporting data of PJSC Gazprom for 2000-2018 [28-31] it is possible to calculate the predicted $\mathrm{Y}^{\wedge}(1)$ for the reporting period for model (1). Substituting successively the values of X1; X2; ...; X4 for 2000-2018 in the model (1), we obtain all $Y i^{\wedge}(1), i=1, \ldots, 19$. Conducting a comparative analysis of the actual $\mathrm{Y}$ and the fitted $\mathrm{Y}^{\wedge}$ for 2000-2018 [28-31], it can be noted that the obtained data $\mathrm{Yi}$ and $\mathrm{Yi}^{\wedge} \wedge(1), i=1, \ldots, 19$ practically coincide. Thus, the linear model (1) can be used for prediction calculations.

\section{CONCLUSION}

Gazprom is one of the largest employers in Russia (the enterprise took 1st place in 2013, 2nd place in 2016 and in 2018 in the top-100 most attractive employers). According to reporting data for 2000-2019 [1-2, 28-31] the staff number of the enterprise is growing from 311.3 thousand people (in 2000) up to 466.1 thousand people (in 2018).

A system of lifelong education was introduced in PJSC Gazprom on the basis of corporate educational institutions due to the increased requirements for production and labor efficiency and for the development of intellectual potential. Best practices and approaches for training and retraining of personnel help to effectively manage the staff knowledge, to build human resources. The staff number who underwent advanced training or professional retraining increased from 80.1 thousand (in 2000) to 381.1 thousand (in 2018). At the same time, the training costs and staff development increased from 145 million rubles (in 2000) to 1,100 million rubles (in 2018) [28-31].

Today, PJSC Gazprom is a modern high-tech company with a strong scientific and technological base capable of developing and implementing its own innovative projects. The innovation development program allows the enterprise to reduce costs and increase competitiveness. R\&D costs, commissioned by the enterprise for 2000-2018, also grew from 1,410 million rubles (in 2005) up to 9,000 million rubles (in 2018). The largest $R \& D$ expenses were 10,800 million rubles in 2014.

The indicators on intellectual property management of PJSC Gazprom are the effectiveness indicators of the implementation of the PJSC Gazprom Innovation Development Program until 2020. Since 2000, PJSC Gazprom organizations have owned 473 patents for objects of patent law, and its number has been constantly growing until 2018 (2555 pcs.) The share of PJSC Gazprom's applications for patent in the total volume of 
enterprise, it can be argued that the pace of development of PJSC Gazprom will not change in the future.

Today, as a result of a targeted staff development program, PJSC Gazprom is able to solve its challenges arising from global crises and domestic crises, and creates all the conditions for the intellectual potential development of the enterprise, inhancing its competitiveness [1-2]. potential of the enterprise boosted the sales revenue from 2000 (540 billion rubles) to 2018 (8224 billion rubles). Studying the statistics and the development trend of the

\section{ACKNOWLEDGMENT}

The publication was supported by the Russian Foundation for Basic Research, grant No 19-29-07168

\section{REFERENCES}

[1] PJSC Gazprom (2018). Gazprom innovation development program until 2025. Retrieved from URL: http://www.gazprom.ru/f/posts/76/904731/prirpassport-2016-11.pdf Accessed: 12.03.2020 [In Rus]

[2] PJSC Gazprom (2017). Gazprom Sustainability Report. Retrieved from URL: https://www.gazprom.ru/f/posts/97/653302/prirpassport-2018-2025.pdf Accessed: 13.03.2020 [In Rus]

[3] N.M. Baranova, D.S. Loginova, (2019) Innovative development of enterprises in Russian energy sector to increase country's competitiveness, International Scientific Conference "Global Challenges and Prospects of the Modern Economic Development" / The European Proceedings of Social \& Behavioural Sciences, 2020. Samara, Future Academy, EpSBS, pp. 606-613. DOI:

https://doi.org/10.15405/epsbs.2020.03.87

[4] I. Lebon, T. Rebière, How many educated workers for your economy? European targets, optimal public spending, and labor market impact. Port Econ J 17, 144 (2018). DOI: https://doi.org/10.1007/s10258-0180142-8

[5] V. Vandenberghe, The Contribution of Educated Workers to Firms' Efficiency Gains: The Key Role of Proximity to the 'Local' Frontier. De Economist 166, 259-283 (2018). DOI: https://doi.org/10.1007/s10645018-9322-2

[6] J. Graafland, N. Noorderhaven, Technological Competition, Innovation Motive and Corporate Social Responsibility: Evidence from Top Managers of European SMEs. De Economist 168, 1-22 (2020). DOI: https://doi.org/10.1007/s10645-019-09351-z
[7] Z.R. Israilova, M.A. Barzaeva, Challenges of effective use of corporations capital. Scientificmethodical journal "Advances in science and education", 2016, no 10(11), pp. 31-32. [In Rus]

[8] R.M. Timerbulatov, Investment in human capital as a factor of improving company competitiveness. Vestnik of Saratov State Socio-Economic University, 2016, vol. 2, no. 61, pp. 40-42 [In Rus]

[9] V.V. Antonenko, E.G. Laktyuhina, G.V. Antonov, Feasibility of investment in Russia's young human capital: employers' sentiment. National Interests: Priorities and Security, 2016, vol. 2, pp. 118-130 [In Rus]

[10] V.N. Belkin, N.A. Belkina, O.A. Antonova, Organizational Capital of the Enterprise. Economy of Region, 2016, vol. 12, no 3, pp. 826-838. DOI: https://doi.org/10.17059/2016-3-18 [In Rus]

[11] N.D. Rogalev, Human capital as a basis for innovative development of the Russian energy industry. Scientific, social and business magazine «The Energy Policy», 2016, no 3, pp. 25-30 [In Rus]

[12] E.G. Khudyakova, Human capital as a factor of competitiveness of the company. International research journal, 2015, no. 6(37), pp. 124-126 [In Rus]

[13] Armstrong, S. Taylor, Armstrong's Handbook of Human Resource Management Practice, M. 14th Edition. London: Kogan Page, 2017, 1040 p.

[14] Zambrano A., Motivating informed decisions. Econ. Theory (2017). DOI: https://doi.org/10.1007/s00199-017-1087-3

[15] M. Bambi, C. Di Girolami, S. Federico, et al. Generically distributed investments on flexible projects and endogenous growth. Econ Theory 63, 521-558 (2017). DOI: https://doi.org/10.1007/s00199-015-0946$\mathrm{Z}$

[16] M. Fleurbaey, On sustainability and social welfare. J. Environ. Econ. Manag. 71, 34-53 (2015) DOI: https://doi.org/10.1016/j.jeem.2015.02.005 
[17] T.A. Pham, Policy volatility and growth. Port Econ J 17, 87-97 (2018). DOI:

https://doi.org/10.1007/s10258-018-0144-6

[18] D.A. Ackerberg \& K. Caves, G. Frazer (2015). Identification properties of recent production function estimators. Econometrica, 83, 2411-2451 DOI: https://doi.org/10.3982/ECTA13408

[19] H. Kim, R.E. Hoskisson, S.H. Lee (2015). Why strategic factor markets matter: "new” multinationals' geographic diversification and firm profitability. Strategic Management Journal 36(4): 518-536.

[20] G.B. Asheim, T. Mitra, Characterizing sustainability in discrete time. Econ Theory (2020). DOI: https://doi.org/10.1007/s00199-020-01250-8

[21] A. Pilipenko \& Z. Pilipenko (2018). Shocks in global economy: Impulse model ofmacroeconomic cycle. In S. Bruno, M. Ziolo (Eds.), Regaining Global Stability After the Financial Crisis (pp. 238-256). Pennsylvania, USA: IGI Global.

[22] B.S. Sergi (Ed.). (2018). Exploring the future of Russia's economy and markets: Towards sustainable economic development. Bingley: Emerald Publishing Limited.

[23] B.S. Sergi (Ed.). (2019). Modeling economic growth in contemporary Russia. Harvard University, USA: Emerald Publishing Limited.

[24] V.M. Matyushok, N.M. Baranova, L.V. Sorokin (2020) Human Capital Impact for Sustainable Economic Growth. In: Sahdev S., Singh R., Kumar M. (eds) Geoecology of Landscape Dynamics. Advances in Geographical and Environmental Sciences. Springer, Singapore, pp. 21-36, Print ISBN978-981-15-2096-9, DOI: https://doi.org/10.1007/978-981-15-2097-6_3
[25] V.M. Matyushok, S.A. Balashova, I.V. Lazanyuk, Basics of econometric modeling using Eviews: tutorial; electronic text data. Moscow: RUND, 2015, 228 p. [In Rus]

[26] J.M. Wooldridge (2015) Introductory econometrics: a modern approach. South-Western Cengage Learning, Mason

[27] M. Magnusson, L. Jonsson, \& M. Villani DOLDA, A regularized supervised topic model for highdimensional multi-class regression. Comput Stat 35, 175-201 (2020). DOI: https://doi.org/10.1007/s00180019-00891-1

[28] PJSC Gazprom (2004). Gazprom reference figures 2000-2004. Retrieved from URL:

https://www.gazprom.ru/f/posts/72/836820/statistika_ru s.pdf Accessed: 11.03.2020 [In Rus]

[29] PJSC Gazprom (2009). Gazprom reference figures 2005-2009. Retrieved from URL:

https:/www.gazprom.ru/f/posts/27/447975/referencefigures-2005-2009_1.pdf Accessed: 11.03.2020 [In Rus]

[30] PJSC Gazprom (2013). Gazprom reference figures 2009-2013. Retrieved from URL:

https://www.gazprom.ru/f/posts/75/972935/gazprom-infigures-2009-2013-ru.pdf Accessed: 11.03.2020 [In Rus]

[31] PJSC Gazprom (2018c). Gazprom reference figures 2014-2018. Retrieved from URL: https://www.gazprom.ru/f/posts/72/692465/gazprom-infigures-2014-2018-ru.pdf Accessed: 11.03.2020 [In Rus] 